University of Nebraska - Lincoln

DigitalCommons@University of Nebraska - Lincoln

Marketing Department Faculty Publications

Marketing Department (CBA)

8-2003

\title{
IT Competency and Firm Performance: Is Organizational Learning a Missing Link?
}

\author{
Michael J. Tippins \\ University of Wisconsin - Oshkosh, tippins@uwosh.edu \\ Ravipreet S. Sohi \\ University of Nebraska-Lincoln, ravisohi@unl.edu
}

Follow this and additional works at: https://digitalcommons.unl.edu/marketingfacpub

Part of the Business Administration, Management, and Operations Commons, Management

Information Systems Commons, Management Sciences and Quantitative Methods Commons, Marketing Commons, and the Strategic Management Policy Commons

Tippins, Michael J. and Sohi, Ravipreet S., "IT Competency and Firm Performance: Is Organizational Learning a Missing Link?" (2003). Marketing Department Faculty Publications. 23.

https://digitalcommons.unl.edu/marketingfacpub/23

This Article is brought to you for free and open access by the Marketing Department (CBA) at DigitalCommons@University of Nebraska - Lincoln. It has been accepted for inclusion in Marketing Department Faculty Publications by an authorized administrator of DigitalCommons@University of Nebraska - Lincoln. 


\title{
IT Competency and Firm Performance: Is Organizational Learning a Missing Link?
}

\author{
Michael J. Tippins \\ College of Business Administration, University of Wisconsin, Oshkosh, Wisconsin \\ Ravipreet S. Sohi \\ College of Business Administration, University of Nebraska-Lincoln, Lincoln, Nebraska \\ Corresponding author - Michael J. Tippins, College of Business Administration, University of Wisconsin Oshkosh, \\ 800 Algoma Blud, Oshkosh, WI 54901-8678; email tippins@uwosh.edu
}

\begin{abstract}
Many companies have developed strategies that include investing heavily in information technology (IT) in order to enhance their performance. Yet, this investment pays off for some companies but not others. This study proposes that organization learning plays a significant role in determining the outcomes of IT. Drawing from resource theory and IT literature, the authors develop the concept of IT competency. Using structural equations modeling with data collected from managers in 271 manufacturing firms, they show that organizational learning plays a significant role in mediating the effects of IT competency on firm performance.
\end{abstract}

Keywords: organizational learning, information technology competency, resource-based view, knowledge management

\section{INTRODUCTION}

Many organizational leaders and strategy scholars would agree that the ability to effectively manage information within the firm has become critically important because it may provide a basis for gaining a competitive advantage. Seen by many as a source of value creation instead of a cost (Sampler, 1998), information has become an invisible asset that, when managed properly, can be used to leverage other firm resources. The ability to obtain information about markets and customers helps to ensure that firms are more attuned to changes in the environment and can result in a competitive advantage over slower, ill-informed competitors (Barney, Wright, and Ketchen, 2001). It is therefore not surprising that many firms have begun to develop strategies that focus on information technology (IT) as a resource to facilitate the effective collection and utilization of informa- tion (e.g., Bharadwaj, 2000; Mata, Fuerst, and Barney, 1995; Nault and Dexter, 1995; Powell and DentMicallef, 1997). However, while as many as half of all companies worldwide are seeking to gain a competitive edge by spending more on IT, a clear understanding of how IT impacts strategy and critical performance outcomes remains unclear (e.g., Berndt and Morrison, 1995). While some firms achieve successful outcomes with regard to their IT endeavors, others continue to fall victim to the technology productivity paradox (Lucas, 1999). As such, in today's knowledge economy, many companies still find that spending on IT far outpaces the perceived benefits derived from it (Mahmood and Mann, 1993). Thus, while managers have begun to realize that the adoption and integration of IT by organizations has become a competitive necessity, they have also begun to realize that there is still much to learn about how best to strategically position IT to ensure the greatest positive effect on firm 
performance. Determining which firm processes and structures will benefit from the integration of IT has therefore become a major hurdle that managers must overcome if they wish to avoid the negative implications of the productivity paradox.

\section{Objectives of this paper}

Even though recent studies have examined the relationship between IT and firm performance, this research stream continues to be hampered by the lack of a widely accepted conceptualization of IT. As Fry (1982) warned two decades ago, by failing to agree upon a common definition of IT, the resulting body of research will continue to be contradictory and rely on differing conceptualizations, levels of analysis, and IT-related measures. Also, the study of IT is complicated by the fact that new IT tools are constantly being developed. As successive generations of new technology become available and are adopted, generalization of empirical findings from previous studies becomes impractical (Huber, 1990). Confounding the problem further is the fact that many of the advantages gained from adopting a specific form of IT tend to be short lived since subsequent innovations that render older technology obsolete inevitably become available. Accordingly, the first objective of this paper is to develop a conceptualization of IT competency in a form that will address these issues. As discussed in the next section, we propose the notion of IT competency consisting of three components: (a) IT knowledge, (b) IT operations, (c) IT objects; and provide an operable measure for this construct.

The second objective of this paper is to develop a better understanding of how IT competency impacts firm performance. While past studies have sporadically examined the role of IT within the firm, it is still not clear how IT affects the specific organizational processes that contribute to improved firm performance (Bharadwaj, 2000). Even though popular literature has attempted to explain technologybased organizational success by focusing specifically on various forms of IT (e.g., laptops, Internet), many information systems and strategic management researchers have tended to conceptualize IT as a useful tool that may facilitate competitive advantage only when combined with existing firm capabilities.

Recent literature suggests that organizational learning is one process that plays an important role in enhancing a firm's capabilities and competitive ad- vantage (e.g., Grant, 1996; Lei, Hitt, and Bettis, 1996; Simonin, 1997) and which may benefit from the judicious application of IT. It has also been argued that for firms to be successful they must complement IT with organizational-level learning processes (Anand, Manz, and Glick, 1998). Yet, empirical work in this area is lacking. Thus, in this paper, we adopt a resource-based perspective to explore how IT can be utilized to gain a competitive advantage by examining the mediating role of organizational learning on the linkage between IT competency and firm performance.

The basic contention of this paper is that merely investing in IT may not necessarily improve firm productivity or profitability. It is the implementation of IT within specific market contexts that is more important. By developing an IT competency, and using it to leverage organizational learning, firms are in a better position to enhance their performance.

In the sections that follow, we begin with a discussion on the role of IT in strategic management. Next, we provide an overview of the resource-based approach that forms the theoretical basis for our work. We then discuss the concepts of IT competency and organizational learning. Following this, we develop hypotheses representing the relationships between IT competency, organizational learning, and key performance outcomes. We test our hypotheses with the structural modeling technique, using data collected from managers in 271 manufacturing firms. We conclude with a discussion of the results and their implications.

\section{CONCEPTUAL BACKGROUND}

\section{Information technology and strategic management}

Embedded in the general stream of research that seeks to understand how firm resources and capabilities are combined to produce some form of competitive advantage, the study of how IT affects the strategic management of organizations continues to demand considerable attention. Prior to 1990, most of the literature focused on the importance of IT and its potential to alter a whole range of strategic and industry structure variables, including cost positions, scale economies, and bargaining power (Cash and Konsynski, 1985; Porter, 1985; Clemons, 1986). The literature also suggests that firm strategies and IT ca- 
pabilities are so closely interrelated that they should be developed concurrently (e.g., Porter and Millar, 1985; Rackoff, Wiseman, and Ullrich 1985).

More recently, the focus of the literature has shifted to the relationship between IT and specific components of firm strategy, such as environmental scanning (Maier, Rainer, and Snyder, 1997), competitive advantage (Mata, Fuerst, and Barney, 1995), organizational performance (e.g., Dollinger, 1984; Powell and Dent-Micallef, 1997; Bharadwaj, 2000), and knowledge accumulation (Bettis and Hitt, 1995; Grant, 1996).

A review of this literature reveals two things. First, the body of empirical research is comparatively small compared to the conceptual and anecdotal work. This current imbalance between the conceptual/anecdotal and empirical literature has created a conspicuous gap in the strategy literature. As more companies turn to technology in an attempt to enhance the bottom line, this gap must be systematically addressed by empirically examining specific organizational processes and structures that may benefit from the adoption of IT. By doing so, a more unequivocal understanding of the relationship between competitive strategy, IT, and performance will begin to emerge.

Second, most of the earlier conceptual work tends to favor the notion that IT can be used favorably to create a competitive advantage and sustain firm performance (Porter, 1985; Porter and Millar, 1985; Rackoff et al., 1985). However, emerging empirical evidence has shown that technology does not necessarily create a competitive advantage and there is no significant direct connection between IT and performance (e.g., Mahmood and Soon, 1991; Zahra and Covin, 1993; Hitt and Brynjolfsson, 1996; Powell and DentMicallef, 1997). To provide a possible explanation for this, we draw on the resource-based view (RBV).

\section{Resource-based view}

Grounded in evolutionary economics and the work of Penrose (1959), the RBV has gained considerable attention during the last decade (Barney et al., 2001). It is based on the precept that firms compete on the basis of resources that are heterogeneously distributed among firms (Barney, 1991), and this resource heterogeneity is responsible for the observed variability in financial performance across firms (Peteraf, 1993). In contrast to the externally focused perspec- tive that seeks to tie a firm's strategy to competitive positioning and environmental factors, the resourcebased perspective focuses on advantages stemming from internal organizational resources. Firms can achieve sustained performance advantages by accumulating resources that produce economic value, are relatively scarce, and can sustain competitive attempts at imitation, acquisition, or substitution (Barney, 1991; Sampler, 1998). According to the RBV, IT per se may not generate a sustainable advantage, because it can be commoditized through competitive imitation and acquisition (Clemons and Row, 1991). However, the advantages of IT can be protected by embedding it in an organization through complementarity and cospecialization (Powell and Dent-Micallef, 1997).

Complementarity is said to exist when the value of one resource is enhanced by the presence of another resource (Powell and Dent-Micallef, 1997). Thus, the value of IT is enhanced when firms use it to develop knowledge stores about its customers, markets, and other factors that influence performance. Strategy literature has recognized the role of knowledge as an important intangible resource for the firm (LeonardBarton, 1995; Nonaka and Takeuchi, 1995; Spender, 1996; Grant, 1996). Knowledge development is a part of organizational learning. Further, learning is said to be more important in creating sustainable competitive advantage because it deals with the process of developing organizational capability rather than just focusing on gaining specific types of knowledge (Schendel, 1996). Consequently, in this paper we focus on the role that organizational learning plays in enhancing the value of IT.

Co-specialization is said to exist if one resource has little or no value without another (Clemons and Row, 1991). For example, a firm possessing the necessary IT hardware will realize very little advantage if it does not have the necessary skills and processes to use it successfully. Our review of the literature indicates that, to a large extent, IT has been examined as a stand-alone resource. Studies have looked at the impact of different types of technologies (EDI, scanning devices, etc.) or IT infrastructure, but to our knowledge no one has examined how IT as a resource can be embedded in an organization and protected through cospecialization. In the next section we use this perspective to develop the concept of IT competency and suggest that it consists of three co- 
specialized resources: IT objects, IT knowledge, and IT operations. We then follow with a discussion of the components of organizational learning and subsequently link IT competency and organizational learning to determine how they interact to enhance firm performance.

\section{IT competency}

Given the increasing importance of information in today's global marketplace (Glazer, 1991), achieving competence with regard to the tools and processes used to manage information has taken on a new urgency. From a resource-based perspective, competencies are inimitable because of idiosyncratic development of resources that have little value outside the context of a specific firm. This inimitability can form the basis of competitive advantage (Lei et al., 1996). Thus, firms that achieve higher levels of IT competency are thought to be in a superior position for managing the "invisible assets" that create market leadership (Itami, 1987).

Drawing from literature streams in marketing (Glazer, 1991), strategy (Leonard-Barton, 1995), and information sciences and technology (Ortega y Gasset, 1983; Mitcham and Mackey, 1983; Taylor, 1971), we conceptualize IT competency as the extent to which a firm is knowledgeable about and effectively utilizes IT to manage information within the firm. Included in this conceptualization is the assumption that firms also possess IT objects (e.g., software, hardware, IT personnel). Cumulatively, the three dimensions of IT competency represent co-specialized resources that provide an indication of the organization's ability to understand and utilize IT tools and processes that are needed to manage market and customer information. Further, while independent, all three components are required to be present in order to achieve IT competency. For example, while many firms possess large stores of IT objects, the firms do not achieve IT competency because they lack the knowledge necessary to utilize the objects effectively. The following section provides a more detailed discussion of each IT competency component.

\section{IT knowledge}

Given that knowledge is "information combined with experience, context, interpretation, and re- flection," it possesses a tacit component that is difficult to quantify (Davenport, De Long, and Beers, 1998: 43). As with other specific domains of knowledge, IT knowledge is distinguishable as a subset of the more general conception of knowledge (Capon and Glazer, 1987). Taylor (1971: 3) defines technical knowledge as "a set of principles and techniques useful to bring about change towards desired ends." Technical knowledge has also been described as contextually based know-how. That is, given certain specific circumstances, the correct sequence of actions and administration of appropriate decision rules can lead to predictable outcomes. In this study, IT knowledge is conceptualized as the extent to which a firm possesses a body of technical knowledge about objects such as computer based systems.

\section{IT operations}

Technical operations, or techniques, comprise activities that are undertaken in order to achieve a particular end (Mitcham and Mackey, 1983). They can be considered the methods, skills, and processes required for completing a focal task (Granstrand, 1982). Nelson, Peck, and Kalachek (1967) suggest that techniques consist of heterogeneous processes, which are mostly directed at the production of economic goods and services. This conceptualization corresponds with Capon and Glazer's (1987) idea of process technology, which is a set of ideas or steps utilized to reach an objective (e.g., a finished product). Technical operations are also thought of as a manifestation of technical knowledge in that the implementation of technical knowledge results in technical operations or skills. In the presence of superior IT knowledge, these skills may become "T-shaped." That is, the skills not only represent a deep understanding of a particular "knowledge domain," but also reflect an ability to export the knowledge to other incongruent operations (Leonard-Barton 1995). For this study IT operations are conceptualized as the extent to which a firm utilizes IT to manage market and customer information.

\section{IT objects}

Relatively easy to measure as indicated by many earlier IT-related studies (e.g., Reardon, Hasty, and Coe, 1996), IT objects act as "enablers" and are largely re- 
sponsible for the current increases in information production and dissemination (Glazer, 1991). As a tool, technical objects refer to artifacts which assist in the "acquisition, processing, storage, dissemination, and use" of information (Martin 1988: 24). For this study the conceptualization of IT objects represents computer-based hardware, software, and support personnel.

\section{Organizational learning}

While there are many definitions and conceptualizations of organizational learning, at a very basic level it is the process by which new knowledge or insights are developed by a firm (Slater and Narver, 1995). Extant literature indicates that organizational learning consists of four components: information acquisition, information dissemination, shared interpretation, and development of organizational memory.

\section{Information acquisition}

This is the process by which firms actively seek out and gather useable information (Kohli and Jaworski, 1990). Information can be acquired from three distinct sources (Slater and Narver, 1995). First, organizations can acquire information through direct experience. These experiences can have either an internal focus (e.g., process improvement) or an external focus (e.g., primary market research). Second, firms can gather information based on the experience of others. For example, Kohli and Jaworski (1990) suggest that informal discussions with customers are often fruitful in terms of supplying new market intelligence. Third, information can be acquired from the organization's own memory mechanisms. Although a fundamental outcome of organizational learning (Sinkula, 1994), memory also serves as a warehouse for information within the firm. In fact to a large extent, the contents of a firm's memory play a significant role in the type of market information that is acquired and how it is interpreted (Moorman and Miner, 1997).

\section{Information dissemination}

Once the firm has acquired market information, it must be distributed to those individuals who need it in order for the learning process to be effective. Information dissemination is the extent to which the infor- mation that is obtained by an organization is shared between its functional units, through formal and informal channels (Maltz and Kohli, 1996; Slater and Narver, 1995). Disseminating information provides a considerable advantage as different perspectives come into play and a sense of shared meaning begins to form.

\section{Shared interpretation}

This refers to the presence of consensus among organizational members with regard to the meaning of information (Slater and Narver, 1995). As the information is disseminated throughout the firm, consensus as to the meaning of the information evolves. This, in turn, leads to global understanding of the information among firm members and helps to clarify how information may impact the firm's future strategy. Once members are in agreement as to the meaning of information, they can then act upon the information in a concerted manner. Shared interpretation also plays a role in the future acquisition and interpretation of information (Slater and Narver, 1995). As the shared understanding of information is committed to organizational memory, future information is evaluated in light of what already exists.

\section{Organizational memory}

The final organizational learning component deals with organizational memory (Slater and Narver, 1995; Walsh and Ungson, 1991). Memory "refers to the amount of stored information or experience an organization has about a particular phenomenon" (Moorman and Miner, 1997: 103). Memory is thought to play two important roles in the organizational learning process. First, it can provide a foundation for change through generative learning processes, and second, it can have a significant impact on the learning process by influencing the type of information that is sought and the manner in which the information is analyzed (Slater and Narver, 1995).

Organizational memory can be characterized as declarative and procedural (Moorman and Miner, 1998b). Declarative memory contains knowledge of facts and events. For example, in a business-to-business context, if a firm is trying to learn more about its customers, declarative memory would include 
knowledge about a customer firm's business objectives, its market conditions, its marketing strategies, competitive positions, etc. Procedural memory contains knowledge about routines, processes, and procedures. These might include procedures to handle routine purchase orders, procedures to identify customer needs, procedures to deal with customer complaints, and so on. While both forms of memory are thought to be important, declarative memory has been linked to general knowledge that is applicable to a wider range of situations. Conversely, the manifestation of procedural memory tends to be more rigid and is associated with domain-specific skills or routines.

\section{HYPOTHESES}

Based on the discussion in the preceding section, we propose a conceptual model shown in Figure 1. In this model, IT competency is conceptualized as a higher-order construct consisting of three domains represented by first order factors: IT knowledge, IT operations, and IT objects. Similarly, organizational learning is conceptualized as a higher-order construct composed of five first-order factors representing information acquisition, information dissemination, shared interpretation, declarative memory, and procedural memory. The contention of our model is that IT competency's effect on firm performance is mediated by organizational learning. Accordingly, we develop and test three hypotheses representing (a) the relationship between IT competency and firm performance, (b) the relationship between IT competency and organizational learning, and (c) the relationship between organizational learning and firm performance.

\section{IT competency and firm performance: a case for par- tial mediation}

While the debate concerning the extent to which IT capabilities can be effectively transferred across firm boundaries persist (Bharadwaj, 2000), a strong case can be made that IT capabilities by themselves are ineffective at providing a basis for sustainable competitive advantage because the capabilities are too eas-

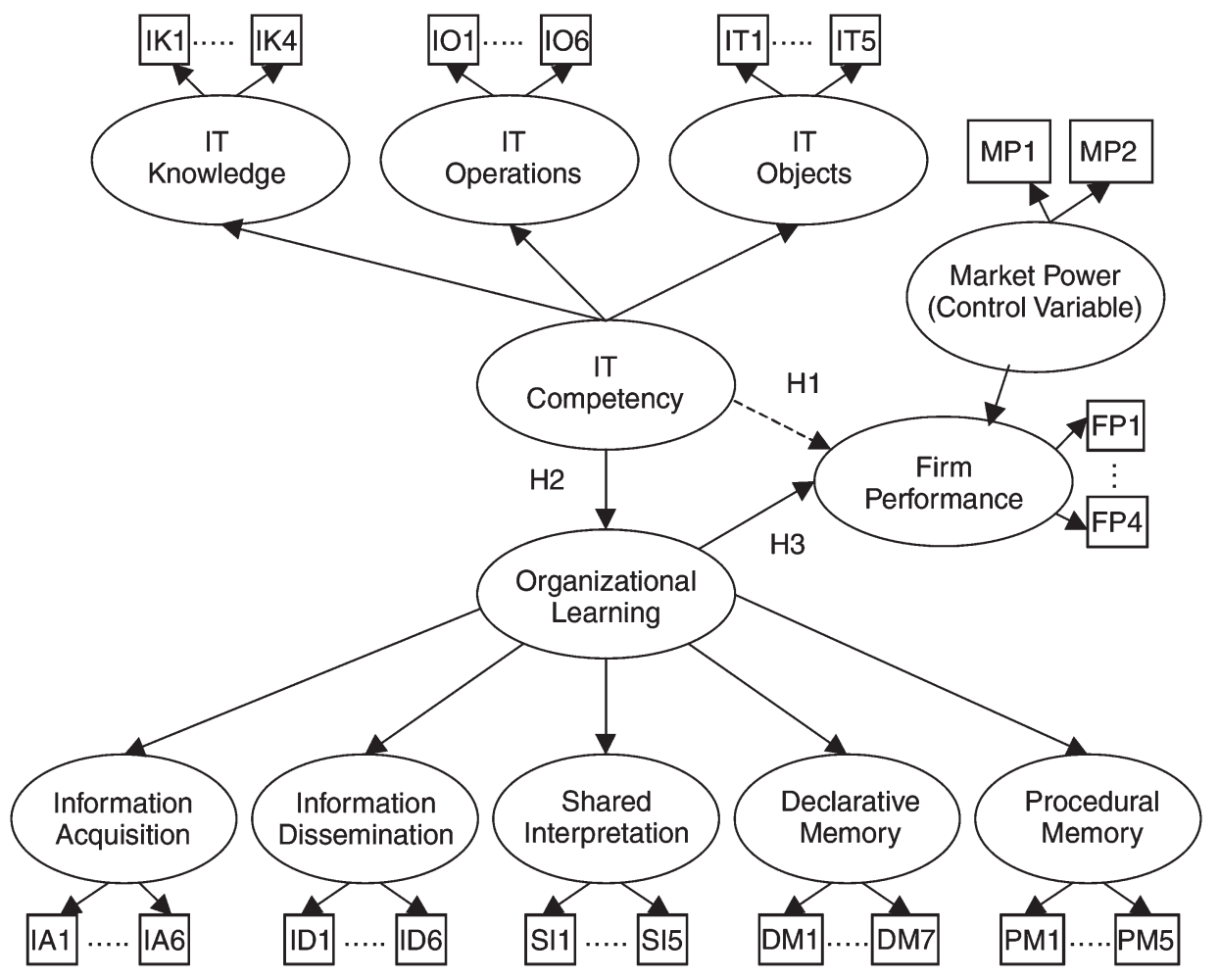

Figure 1. Conceptual model. IT competency and organizational learning are second-order factors. To reduce clutter, only two indicants are shown for each first-order factor. Market power is a control variable composed of relative firm size and market share. 
ily duplicated. Further, as suggested by Clemons and Row (1991: 290), the "benefits resulting from an innovative application of information technology can be more readily defended if the system exploits unique resources of the innovating firm so that competitors do not fully benefit from imitation." Thus, we expect that the impact of IT on a firm's performance cannot be measured directly, but can only be quantified by examining the indirect effect on some intervening firm capability (e.g., organizational learning).

Support for our claim that the relationship between IT competency and firm performance is partially mediated by intervening factors stems directly from the resource-based perspective. Given the wide range of benefits realized by different firms with regard to IT investment, simple ownership of IT by an organization does not support the thesis that IT will positively impact critical outcome measures (e.g., profitability, ROI). As suggested earlier, while some firms have realized positive benefits, many other firms have fallen victim to the productivity paradox (Lucas, 1999) and have actually experienced negative returns from investing in IT - the implication being that IT, in and of itself, may not hold the answer to enhanced performance, but rather must be incorporated into the firm and combined with other firm capabilities to produce positive effects. Therefore the following hypothesis is set forth:

Hypothesis 1: The relationship between IT competency and firm performance is mediated by organizational learning.

\section{IT competency and organizational learning}

IT provides organizational members with quick and effective access to the right amounts of information (Hope and Hope, 1997). By accelerating the speed at which information is acquired and disseminated throughout the firm, IT can help ensure that each firm member is current with regard to relevant market information. For example, Connolly and Thorn (1990) discuss the use of discretionary databases and state that information that flows electronically into the firm can be quickly made available to both the original recipient and secondary recipients alike. Therefore, it is expected that as firms develop IT competency they are likely to enhance their ability to acquire and disseminate information.
Shared interpretation is often complicated by the fact that organizational members must cope with an ever-shifting knowledge base that contributes to changes in organizational objectives and goals (Levinthal and March, 1993). In order to avoid confusion, mechanisms must be implemented to keep members current with regard to both available information and organizational goals. IT competency should aid in the development of consensus, since one of the benefits of IT is that it enables organizational members to be more active in the information management process (Hiltz and Wellman, 1997). Due to IT-enhanced connectivity, firm members can more easily share individual interpretations of the information, making consensus development more efficient.

And finally, organizational memory is also expected to be positively affected by the development of a firm's IT competency. As organizational learning continues to generate output, both declarative and procedural memory "bins" accumulate valuable information. IT provides the necessary mechanisms for storage of this information. In order to be useful, however, information stored in the memory must be accessible to firm members and must be in a form that will enable each member to interpret it in a similar manner, thereby becoming a part of the whole firm's knowledge base. IT, with its protocols and platform standards, provides an ideal mechanism for connecting widely dispersed individuals via a common system (e.g., intranets) and enabling firm members to access more easily the knowledge that is stored in memory bins, so that new information can be interpreted and synthesized with existing knowledge. Given the potential impact that IT competency has on the various organizational learning processes, the following hypothesis is set forth:

\section{Hypothesis 2: IT competency is positively related to organizational learning.}

\section{Organizational learning and firm performance}

Financial performance (i.e., profitability, ROI) is said to be enhanced by an organization's ability to learn (Day, 1994a; Slater and Narver, 1995). Firms that are able to learn about customers, competitors, and regulators stand a better chance of sensing and acting upon events and trends in the marketplace (Day, 1994b). Also, learning organizations are better versed in strategies for dealing with customers and compet- 
itors alike, which, in turn, should lead to superior profitability (Slater and Narver, 1995). Sales growth is another performance indicator that is said to be enhanced by a firm's ability to learn. A firm that actively learns about its customers is in a position to offer more appropriate and finely targeted products. This should result in a higher level of sales growth (Slater and Narver, 1995). And finally, the level of customer retention can also be linked to organizational learning. Here again, a firm's ability to learn and target customer wants and needs more precisely is thought to result in higher levels of customer satisfaction, which should lead to superior levels of customer retention (Slater and Narver, 1995). Together the four performance measures are summated to provide a global indicator of how well a firm is performing relative to direct competitors. The following hypothesis is set forth:

Hypothesis 3: There is a positive relationship between organizational learning and firm performance.

\section{RESEARCH METHODOLOGY}

\section{Sample and data collection}

Our sample consists of manufacturing organizations in SIC codes 35 (Industrial \& Commercial Machinery Manufacturers), 36 (Electronic \& Other Electrical Equipment Manufacturers), 37 (Transportation Equipment Manufacturers), and 38 (Measuring \& Analyzing Instruments Manufacturers). We purposely selected a wide range of firms and industries for two reasons. First, information systems continue to contribute significantly to greater effectiveness in a wide range of manufacturing industries. Second, we used a diverse sample to increase the generalizability of our results.

Mail surveys were sent to 524 executives, who had been identified as appropriate key respondents based on two criteria: (a) possession of sufficient knowledge, and (b) adequate level of involvement with regard to the issues under investigation (Campbell, 1955). To further ensure the validity of our data and ensure that we had isolated the correct key informant, we included validation items in the research instrument. We used these items to again verify that the executives who responded were fully qualified to provide the information we requested.

Four weeks after the initial mailing, a follow-up survey was sent to those individuals who failed to return completed surveys. In both mailings, a personalized cover letter and a postage paid return envelope accompanied the survey. Given the low response rates associated with organizational research, we included a one-dollar bill with each survey sent out in the first wave. Further, as an additional incentive, all respondents were promised a complimentary summary of the results. A total of 271 useable surveys were returned, for a response rate of 52 percent.

To check for nonresponse bias, we compared the respondents with the nonrespondents based on (a) prescreening variables, and (b) firm characteristics in terms of SIC codes, sales turnover, and number of employees. We also compared the early and late respondents in terms of demographic characteristics and model variables. These comparisons did not reveal any significant differences, indicating that nonresponse bias was not a problem.

To assess the degree to which common method bias might present a problem, we subjected all scale items for similar constructs to principal component analysis with a varimax rotation (see, for example, Seibert, Kraimer, and Liden, 2001). Results indicated that the items loaded cleanly on the factors representing the expected constructs. Thus, we found no general factor that would have emerged due to common method variance.

\section{Measures}

Our measures are shown in the Appendix. Some of the scales were adopted from previous literature; others were developed for this study.

\section{IT competency (ITCOMP)}

Seven-point Likert scales were used to operationalize the three dimensions of IT competency, namely, IT knowledge (ITKNOW), IT operations (ITOPS), and IT objects (ITOBJECT). This is a new scale and the theoretical domain for the scale items was drawn from literatures in marketing (e.g., Glazer, 1991), IT (e.g., Mata, Fuerst, and Barney, 1995), and information sciences (e.g., Contractor and Eisenberg, 1990).

\section{Organizational learning (ORGLEARN)}

Seven-point Likert scales were also used to operationalize the dimensions of organizational learning. 
Information acquisition (INFOACQ) was measured by a scale adapted from Baker and Sinkula (1999). Items used to measure information dissemination (INFODISS) were adapted from Baker and Sinkula (1999) and Kohli, Jaworski, and Kumar (1993). New scales were developed for measuring shared interpretation (SHARINT), declarative memory (DECMEM), and procedural memory (PROCMEM). The theoretical domain for these scale items was based on Slater and Narver (1995) and Moorman and Miner (1998a).

\section{Firm performance (FIRMPERF)}

As with obtaining other types of sensitive data, identifying optimal measures for a firm's performance is inherently problematic. Given the potential competitive implications of revealing such information, it is not surprising that many respondents are hesitant to report information pertaining to such indicators as profitability and ROI. In order to avoid the omission of sensitive performance data, a more indirect approach for collecting the data was utilized. Instead of directly asking respondents to report objective measures of their firm's performance, they were asked to report how well their firm performed during the last 3 years relative to all other direct competitors in terms of profitability (PROFIT), ROI, customer retention (CUSTRENT), and sales growth (SALEGROW). Similar indirect measures of firm performance have been used in prior strategy research when financial statement data are either unavailable or when they do not allow for accurate comparisons amongst firms (e.g., Dess, 1987; Powell, 1992; Powell and Dent-Micallef, 1997; Spanos and Lioukas, 2001).

\section{Control variables}

To account for extraneous sources of variation in firm performance, we included market power (MARKPOW) as a control variable in our model. According to market power theory, large firms with high market shares can exercise market power to enhance their performance by obtaining inputs at lower costs, dictating prices, and extracting concessions from suppliers and distributors (Schroeter, 1988; Staten, Umbeck and Dunkelberg, 1988). Two items were used to assess market power. The first item (SIZE) assessed the degree to which the firm was larger or smaller than its largest competitor in terms of size. The second item (SHARE) assessed the degree to which the firm had a larger or smaller market share in its principal market, relative to its largest competitor.

\section{Psychometric properties of measurement scales}

The psychometric properties of the measurement scales were assessed in accordance with accepted practices (Gerbing and Anderson, 1988) and included establishment of content validity, reliability, discriminant validity, convergent validity, and scale dimensionality (see Table 1 for means, standard deviations, and factor correlations). Content validity was established through personal interviews with knowledgeable industry experts (e.g., marketing managers and information management specialists). Considerable effort was made during this field-based validation to ensure that the scale items were relevant and generalizable across the industries in our sample. After purifying the initial scales through exploratory factor analysis and item-to-total correlations, we computed coefficient alpha to assess scale reliability. All scales achieved acceptable coefficient alphas of at least 0.70 (Nunnally, 1978). Discriminant validity was assessed through confirmatory factor analysis (CFA) by comparing the $\chi^{2}$ differences between a constrained confirmatory factor model (where the interfactor correlation is set to 1 , indicating they are the same construct) and an unconstrained model (where the interfactor correlation was free). All $\chi^{2}$ differences were found to be significant, providing evidence of discriminant validity (Anderson and Gerbing, 1988). CFA was also used to establish convergent validity by con- firming that all scale items loaded significantly on their hypothesized construct factors (Anderson and Gerbing, 1988). To confirm dimensionality of the higher-order constructs - IT competency and organizational learning-we ran second-order CFAs. The loadings of the measurement items on the first-order factors, and the loadings of the first-order factors on the second-order factors, were all significant at $p<0.001$. Further, the comparative fit index (CFI) exceeded the recommended norm of 0.90 for both the models (CFI $=0.98$ for IT competency and 0.97 for organizational learning), indicating good model fits and a confirmation of the scale dimensionality. 


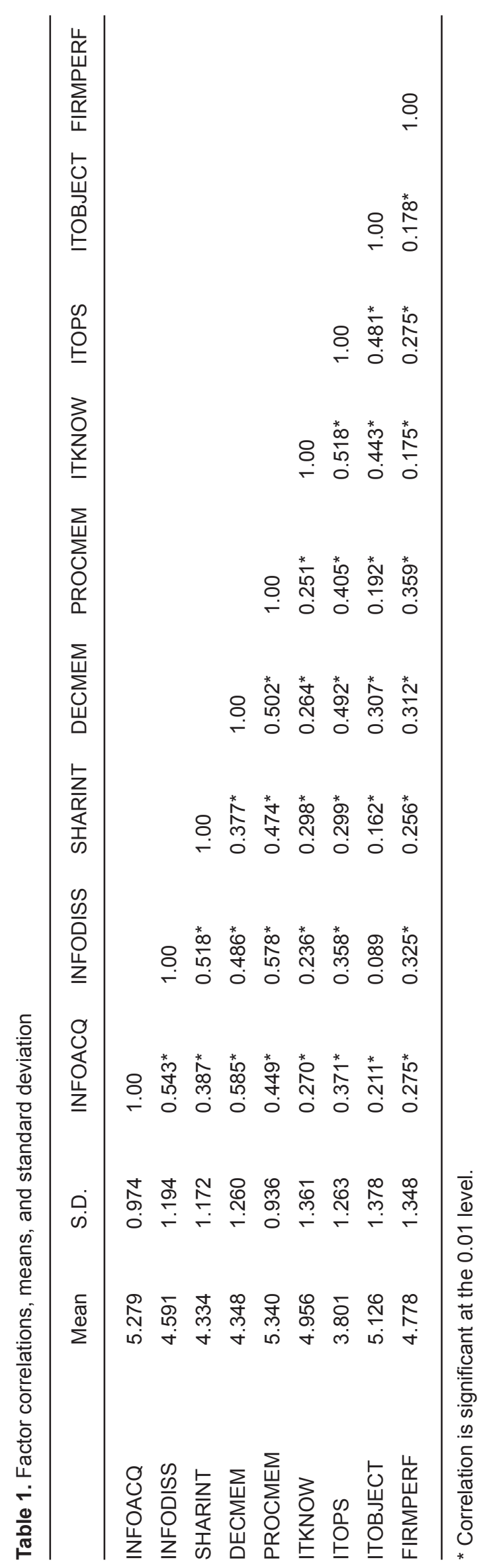




\section{ANALYSIS AND RESULTS}

We used structural equations methodology with the elliptically reweighted least square (ERLS) method offered by EQS to test our hypothesized model. The ERLS method assumes a multivariate elliptical distribution that is a more generalized form of the multivariate normal distribution assumed by the commonly used maximum likelihood (ML) method. According to Sharma, Durvasula, and Dillon (1989: 220), "the performance of ERLS is equivalent to that of ML for normal data and superior to that of other estimation techniques for non-normal data."

Adopting the approach used by Singh, Goolsby, and Rhoads (1994), we checked for the presence of a mediating effect, by performing a competing model analysis (i.e., two substantive models are estimated and evaluated for significant differences). The first model (direct effects) examined the direct relationship between IT competency and firm performance, while a second model (partial mediation) examined the same relationship with organizational learning acting as a mediator. The mediating effect of organizational learning on the relationship between IT competency and firm performance is said to be supported when: (1) the partial mediation model explains more variance in firm performance than the direct model, (2) there is a significant relationship between IT competency and organizational learning, (3) a significant relationship between IT competency and firm performance (as observed in the direct model) is greatly diminished or eliminated in the partial mediation model, and (4) there is a significant relationship between organizational learning and firm performance.

\section{Results of competing models analysis}

Table 2 shows the results of the competing model analysis. Although the $\chi_{2}$ statistic for each model is significant, other relevant fit indices indicate good overall fit. The results show that organizational learning mediates the relationship between IT competency and firm performance. First, the partial mediation model explains more variance in firm performance than the direct effects model (0.28 vs. 0.21$)$. Second, positive relationships exist between IT competency and organizational learning $(\mathrm{H} 2: \beta=0.504, t=4.94, p$ $<0.01$ ) and organizational learning and firm performance (H3: $\beta=0.371, t=4.03, p<0.01)$. And third, the significant relationship between IT competency and firm performance indicated in the direct effects model $(\beta=0.166, t=2.07)$ becomes nonsignificant in the partial mediation model ( $\mathrm{H} 1: \beta=0.014, t=0.154)$. Together these three points provide compelling evidence that there exists a discernible mediating effect of organizational learning on the relationship between IT competency and firm performance. Thus, the partial mediation model represents a significant improvement over the direct effects model and further supports the resource-based perspective.

\section{DISCUSSION}

The possibility that IT can provide firms with a basis for competitive advantage has received a great deal of attention in recent years. While some claim that efficiencies created by investments in IT enhance firm profitability, others disagree. The few studies that have examined the relationship between IT and firm performance have provided findings that tend to be either mixed or inconclusive. However, there are three reasons to believe that the studies do not adequately capture and measure the effects of IT.

First, prior studies have focused on the adoption of a specific type of technology as a proxy for the IT competency of a firm, and found mixed results. For example, Dos Santos and Peffers (1995) found no significant relationship between ATM application and measures of firm performance such as market share and income. We propose that to assess IT competency one needs to look beyond specific technologies, to three interrelated components: IT objects, IT knowledge, and IT operations. We further propose that all three components must be present for a firm to achieve IT competency.

Second, the effects of IT can be indirect. Specifically, we show that organizational learning is a mediator between IT competency and firm performance. This notion is consistent with, and builds on, some of the earlier work in this area. For example, Powell and Dent-Micallef (1997) found that IT enhances firm performance only when it is used to leverage preexisting, complementary human and business resources. Similarly, Neo (1988) states that IT by itself does not lead to success, but can help to facilitate successful outcomes only when integrated 
Table 2. Test results of partial mediation effect: the mediating role of organizational learning on the relationship between IT competency and firm performance

\begin{tabular}{|c|c|c|}
\hline Parameter ${ }^{\mathrm{C}}$ & Direct effects model ${ }^{a}$ & Partial mediation model ${ }^{b}$ \\
\hline \multicolumn{3}{|l|}{ Hypothesized paths } \\
\hline ITCOMP $\rightarrow$ FIRMPERF $(\mathrm{H} 1)$ & $0.166(2.07)$ & $0.014(0.15)$ \\
\hline ITCOMP $\rightarrow$ ORGLEARN (H2) & - & $0.504(4.94)$ \\
\hline ORGLEARN $\rightarrow$ FIRMPERF $(\mathrm{H} 3)$ & - & $0.371(4.03)$ \\
\hline \multicolumn{3}{|l|}{ Control measure } \\
\hline MARKPOW $\rightarrow$ FIRMPERF & $0.423(3.09)$ & $0.376(2.79)$ \\
\hline \multicolumn{3}{|l|}{ Measurement model and first-order factors } \\
\hline ITCOMP $\rightarrow$ ITKNOW e & $0.681^{d}$ & $0.626^{d}$ \\
\hline ITCOMP $\rightarrow$ ITOPS & $0.788(6.94)$ & $0.898(7.03)$ \\
\hline ITCOMP $\rightarrow$ ITOBJECT & $0.588(5.94)$ & $0.505(5.24)$ \\
\hline ORGLEARN $\rightarrow$ INFOACQ ${ }^{e}$ & - & $0.711(7.39)$ \\
\hline ORGLEARN $\rightarrow$ INFODISS & - & $0.827(10.90)$ \\
\hline ORGLEARN $\rightarrow$ SHARINT & - & $0.725(9.10)$ \\
\hline ORGLEARN $\rightarrow$ DECMEM & - & $0.746(9.08)$ \\
\hline ORGLEARN $\rightarrow$ PROCMEM & - & $0.919^{d}$ \\
\hline FIRMPERF $\rightarrow$ CUSTRENT & $0.307^{d}$ & $0.270^{d}$ \\
\hline FIRMPERF $\rightarrow$ SALEGROW & $0.576(8.72)$ & $0.577(8.32)$ \\
\hline FIRMPERF $\rightarrow$ PROFIT & $0.969(15.61)$ & $0.950(14.57)$ \\
\hline FIRMPERF $\rightarrow$ ROI & $0.935(14.96)$ & $0.952(14.61)$ \\
\hline MARKPOWR $\rightarrow$ SHARE & $0.514 \mathrm{~d}$ & $0.508^{d}$ \\
\hline MARKPOWR $\rightarrow$ SIZE & $0.518(4.44)$ & $0.513(4.11)$ \\
\hline \multicolumn{3}{|l|}{ Goodness-of-fit statistics } \\
\hline$x^{2}$ & $=415.80(p<0.001)$ & $=1801.95(p<0.001)$ \\
\hline d.f. & $=230$ & $=1273$ \\
\hline Bentler-Bonnett normed fit index (NFI) & $=0.924$ & $=0.911$ \\
\hline Bentler-Bonnett non-normed fit index (NNFI) & $=0.964$ & $=0.972$ \\
\hline Comparative fit index (CFI) & $=0.965$ & $=0.972$ \\
\hline Average off-diagonal absolute standardized residuals & $=0.073$ & $=0.076$ \\
\hline
\end{tabular}

a. Includes only the direct effect of IT competency on firm performance.

b. Includes the direct effect of IT competency on firm performance and the mediating effect of organizational learning on the relationship between IT competency and firm performance.

c. Parameter estimates are standardized with $t$-values shown in parentheses.

d. Indicant loading fixed at 1 to set the scale.

e. IT competency and organizational learning are second-order factors. For the sake of brevity, only the first-order loadings are shown.

The item loadings for these first-order factors were all significant at $p<0.001$.

into the firm's strategic planning process. Thus, recent studies that focus on a direct relationship between IT and firm performance fail to take into consideration those intervening firm capabilities that are enhanced by IT and that are the true facilitators of performance enhancement.

Third, many previous studies have relied on the erroneous assumption that adoption of IT would enhance performance (Dewett and Jones, 2001). While IT can improve efficiencies, it may not provide a competitive advantage, because the same technology could be adopted by competing firms. We propose that IT-related benefit can only be realized when a firm develops IT competency and then uses it as a set of co-specialized resources to leverage other complementary resources. The results of our study support our hypotheses and provide additional insights into how IT resources may be utilized to leverage processes such as organizational learning in order to influence firm performance.

\section{Limitations}

Our results must be viewed in light of the study's limitations. Even though we sampled a broad range of industries in SIC codes 35-38, the generalizability of the results is only limited to these industries. Further research is needed to determine the applicability of these results to other industries. As with all cross-sectional research, the hypotheses tested in this research represent a "snapshot" in time. While it is likely that the conditions under which 
the data were collected will remain essentially the same, there are no guarantees that this will be the case. Also, the data were collected from key respondents. This is currently the standard methodology in strategy research but is known to suffer from certain drawbacks. While we tried to correct these drawbacks through careful selection of the respondents and a cross-check of their knowledgeability and involvement, the drawbacks cannot be completely ruled out. Potential common method variance is also inherent in all single-respondent surveys. We checked for the presence of this variance through a principal component analysis and did not find any general methods factor. However, this limitation must be kept in mind. Finally, even though we used the structural equations method, interpretation of causality between the constructs should be treated with caution. Notwithstanding these limitations, our study makes a number of important contributions.

\section{Theoretical contributions}

Our study makes a contribution to the RBV by supporting the perspective that a firm's competitive advantage and performance are a function of complex inimitable resources that are embedded within the organization (Barney, 1991; Peteraf, 1993). Further, by showing that the knowledge acquired through organizational learning can mediate the effect of IT competency on firm performance, we provide evidence that the usefulness of firm resources varies with changes in firm knowledge (Penrose, 1959).

A second related contribution of our study is to the emerging knowledge-based theory of the firm, which posits that knowledge is a fundamental source of value in building firm capabilities (Grant, 1996). The quality of knowledge created and the integration mechanisms constitute the ultimate sources of competitive advantage (Nonaka and Takeuchi, 1995; Spanos and Lioukas, 2001). While the importance of knowledge in the firm has been recognized in the strategy literature (Schendel, 1996), empirical work on knowledge creation and its impact on firm outcomes is still very limited.

A methodological contribution of our study is in the development and empirical validation of scales to assess IT competency and organizational learning. As discussed earlier, while the role of IT as a source of competitive advantage has received a great deal of interest from strategy researchers, most of the work has been conceptual. The few empirical studies that have examined the role of technology have primarily looked at the adoption and performance impact of specific types of technologies. We offer a multidimensional scale to assess IT competency and, to our knowledge, this is one of the first attempts to do so. We also offer a more comprehensive measure of organizational learning. Prior scales have focused on only certain aspects of learning such as information acquisition and dissemination (Sinkula, Baker, and Noordewier, 1997; Baker and Sinkula, 1999) or overall organizational memory (Moorman and Miner, 1997, 1998a). While shared interpretation, procedural memory, and declarative memory were discussed in the literature as components of organizational learning, no scales were available to assess these constructs. Our scales offer items for each of the organizational learning components and links them together through a second order latent factor structure. By testing these scales across a wide range of industries, we have shown that they also provide a fair degree of generalizability.

\section{Managerial implications}

The importance of understanding how IT affects the organization becomes more critical and can be better appreciated in light of the significant percentage of capital investment that is being allocated to it (Lucas, 1999). Firm adoption of computer-based IT has become widespread as organizations continue to search for ways in which to manage information more efficiently. Many managers, however, continue to find that simply adopting a technology designed to facilitate information management and sharing is often not enough, especially when it cannot be utilized to leverage other firm-specific capabilities. And, as noted by Porter (1985), the imprudent integration of such IT systems may eventually lead to a less desirable competitive position within an industry. This sentiment is echoed by Powell and Dent- Micallef (1997: 395), who report that while they found little evidence of a direct effect of IT on performance, "ITs probably did weaken some firms' competitive positions." This study provides additional insights for why some firms may not be realizing benefits from investing in IT. Specifically, the results provide evidence that firms seeking strategic advantage solely by developing IT competency 
may not necessarily realize enhanced performance; the firms must focus their attention on intervening processes such as organizational learning in order to determine what benefits are being derived from ITbased information systems.

Related, this research draws attention to the fallacy of "throwing" IT resources into the organizational mix with the hope of improving bottom line performance. This problem is widespread and continues to be perpetuated by the myth that IT can fix almost any problem. Companies that continue to spend significant amounts of money on their technical infrastructures are routinely confounded when pressed to assess the return on their IT investments (e.g., Berndt and Morrison, 1995). Results from this research suggest that managers should not focus on the bottom line, but should instead be more concerned with increased capabilities and efficiencies associated with the IT-enhanced processes and structures (e.g., learning processes), since this is where the real benefits can be found.

Acknowledgments - The authors wish to thank Jakki Mohr and Chris Lee for their helpful comments on earlier drafts of this manuscript. Research support provided by the University of Nebraska-Lincoln Marketing Department is also gratefully acknowledged.

\section{REFERENCES}

Anand V, Manz CC, Glick WH. 1998. An organizational memory approach to information management. Academy of Management Review 23(4): 796-809.

Anderson JC, Gerbing DW. 1988. Structural equation modeling in practice: a review and recommended two-step approach. Psychological Bulletin 103(3): 411-423.

Baker WE, Sinkula JM. 1999. The synergistic effect of market orientation and learning orientation on organizational performance. Journal of the Academy of Marketing Science 27(4): 411-427.

Barney JB. 1991. Firm resources and sustained competitive advantage. Journal of Management 17(1): 99-120.

Barney JB, Wright M, Ketchen DJ Jr. 2001. The resource- based view of the firm: ten years after 1991. Journal of Management 27: 625-641.

Berndt ER, Morrison CJ. 1995. High-tech capital formation and economic performance in U.S. manufacturing industries: an exploratory analysis. Journal of Econometrics 65: 9-43.

Bettis RA, Hitt MA. 1995. The new competitive landscape. Strategic Management Journal, Summer Special Issue 16: 7-19. Bharadwaj AS. 2000. A resource-based perspective on infor- mation technology capability and firm performance: an empirical investigation. MIS Quarterly 24(1): 169-196.

Campbell DT. 1955. The informant in quantitative research. American Journal of Sociology 60(January): 339-342.

Capon N, Glazer R. 1987. Marketing and technology: a strategic coalignment. Journal of Marketing 51(July): 1-14.

Cash J, Konsynski B. 1985. IS redraws competitive boundaries. Harvard Business Review 63(2): 134-142.

Clemons EK. 1986. Information systems for sustainable competitive advantage. Information and Management 11: 131-136.

Clemons EK, Row MC. 1991. Sustaining IT advantage: the role of structural differences. MIS Quarterly 15(3): 275-294.

Connolly T, Thorn BK. 1990. Discretionary databases. In Organizations and Communication Technology, Fulk J, Steinfield C (eds). Sage: Newbury Park, CA; 219-233.

Contractor NS, Eisenberg E. 1990. Communication networks and new media in organizations. In Organizations and Communication Technology, Fulk J, Steinfield C (eds.). Sage: Newbury Park, CA; 143-172.

Davenport TH, De Long DW, Beers MC. 1998. Successful knowledge management projects. Sloan Management Review, Winter: 43-57.

Day GS. 1994a. Capabilities of market-driven organizations. Journal of Marketing 58(October): 37-52.

Day GS. 1994b. Continuous learning about markets. California Management Review, Summer: 9-31.

Dess G. 1987. Consensus on strategy formulation and organizational performance: competitors in a fragmented industry. Strategic Management Journal 8(3): 259-277.

Dewett T, Jones GR. 2001. The role of information technology in the organization: a review, model, and assessment. Journal of Management 27: 313-346.

Dollinger MJ. 1984. Environmental boundary spanning and information processing effects on organizational performance. Academy of Management Journal 27(2): 351-368.

Dos Santos BL, Peffers K. 1995. Rewards to investors in innovative information technology applications: first movers and early followers in ATMs. Organization Science 6(3): 241-259.

Fry LW. 1982. Technology-structure research: three critical issues. Academy of Management Journal 25(3): 532-552.

Gerbing DW, Anderson JC. 1988. An updated paradigm for scale development incorporating unidimensionality and its assessment. Journal of Marketing Research 25: 186-192.

Glazer R. 1991. Marketing in an information-intensive environment: strategic implications of knowledge as an asset. Journal of Marketing 55(October): 1-19.

Granstrand O. 1982. Technology, Management, and Markets. St Martin's Press: New York.

Grant RM. 1996. Toward a knowledge-based theory of the firm. Strategic Management Journal, Winter Special Issue 17: 109-122. 
Hiltz SR, Wellman B. 1997. Asynchronous learning networks as a virtual classroom. Communications of the ACM 40(9): 44-49.

Hitt LM, Brynjolfsson E. 1996. Productivity, business profitability, and consumer surplus: three different measures of information technology value. MIS Quarterly 20(2): 121-143.

Hope J, Hope T. 1997. Competing in the Third Wave. Harvard Business School Press: Boston, MA.

Huber GP. 1990. A theory of the effects of advanced information technologies on organizational design, intelligence, and decision making. Academy of Management Review 15(1): 47-71.

Itami H. 1987. Mobilizing Invisible Assets. Harvard University Press: Cambridge, MA.

Kohli AK, Jaworski BJ. 1990. Market orientation: the construct, research propositions, and managerial implications. Journal of Marketing 54(April): 1-18.

Kohli AK, Jaworski BJ, Kumar A. 1993. MARKOR: a measure of market orientation. Journal of Marketing Research 30(November): 467-477.

Lei D, Hitt MA, Bettis R. 1996. Dynamic core competencies through meta-learning and strategic context. Journal of Management 22(4): 549-569.

Leonard-Barton D. 1995. Wellsprings of Knowledge. Harvard Business School Press: Boston, MA.

Levinthal DA, March JB. 1993. The myopia of learning. Strategic Management Journal, Winter Special Issue 14: 95-112.

Lucas HC. 1999. Information Technology and the Productivity Paradox. Oxford University Press: New York.

Mahmood M, Mann GJ. 1993. Measuring the organizational impact of information technology investment: an exploratory study. Journal of Management Information Systems 10(1): 97-122.

Mahmood M, Soon SK. 1991. A comprehensive model for measuring the potential impact of information technology on organizational strategic variables. Decision Sciences 22(4): 869-897.

Maier JL, Rainer RK Jr, Snyder CA. 1997. Environmental scanning for information technology: an empirical investigation. Journal of Management Information Systems 14(2): 177-201.

Maltz E, Kohli AK. 1996. Market intelligence dissemination across functional boundaries. Journal of Marketing Research 33(February): 47-61.

Martin WJ. 1988. The Information Society. Eastern Press: London.

Mata FJ, Fuerst WL, Barney JB. 1995. Information technology and sustained competitive advantage: a resource-based analysis. MIS Quarterly, December: 487-504.

Mitcham C, Mackey R. 1983. Philosophy and Technology: Readings in the Philosophical Problems of Technology. Free Press: New York.

Moorman C, Miner AS. 1997. The impact of organizational memory on new product performance and creativity. Journal of Marketing Research 34(February): 91-106.

Moorman C, Miner AS. 1998a. The convergence of planning and execution: improvisation in new product development. Journal of Marketing 61(July): 1-21.

Moorman C, Miner AS. 1998b. Organizational improvisation and organizational memory. Academy of Management Review 23(October): 698-723.

Nault BR, Dexter AS. 1995. Added value and pricing with information technology. MIS Quarterly December: 449-463.

Nelson RR, Peck MJ, Kalachek ED. 1967. Technology, Economic Growth, and Public Policy. Brookings Institution: Washington, DC.

Neo BS. 1988. Factors facilitating the use of information technology for competitive advantage: an exploratory study. Information and Management 15: 191-201.

Nonaka I, Takeuchi H. 1995. The Knowledge Creating Company: How Japanese Companies Create the Dynamics of Innovation. Oxford University Press: New York.

Nunnally JC. 1978. Psychometric Theory. McGraw-Hill: New York.

Ortega y Gasset J. 1983. Thoughts on Technology. Philosophy and Technology: Readings in the Philosophical Problems of Technology. Mitcham C, Mackey R (eds) Free Press: New York.

Penrose ET. 1959. The Theory of the Growth of the Firm. Oxford University Press: Oxford.

Peteraf M. 1993. The cornerstone of competitive advantage: a resource-based view. Strategic Management Journal 14(3): 179-191.

Porter M. 1985. Competitive Advantage. Free Press: New York.

Porter M, Millar V. 1985. How information gives you competitive advantage. Harvard Business Review 65(4): 149-160.

Powell TC. 1992. Organizational alignment as competitive advantage. Strategic Management Journal 13(7): 551-558.

Powell TC, Dent-Micallef A. 1997. Information technology as competitive advantage: the role of human, business, and technology resources. Strategic Management Journal 18(5): 375-405.

Rackoff NC, Wiseman C, Ullrich W. 1985. IS is for competitive advantage: implementation of a planning process. MIS Quarterly 9: 285-294.

Reardon J, Hasty R, Coe B. 1996. The effect of information technology on productivity in retailing. Journal of Retailing 72(4): 445-461.

Sampler JL. 1998. Redefining industry structure for the information age. Strategic Management Journal, Special Issue 19: 343-355. Schendel D. 1996. Editor's introduction to the 1996 Winter Special Issue: Knowledge and the firm. Strategic Management Journal, Winter Special Issue 17: 1-4.

Schroeter JR. 1988. Estimating the degree of market power in beef packing industry. Review of Economics and Statistics 70(February): 158-162. 
Seibert SE, Kraimer ML, Liden RC. 2001. A social capital theory of career success. Academy of Management Journal 44(2): 219-237.

Sharma S, Durvasula S, Dillon W. 1989. Some results of the behavior of alternate covariance structure estimation procedures in the presence of nonnormal data. Journal of Marketing Research 26(May): 214-221.

Simonin BL. 1997. The importance of collaborative know-how: an empirical test of the learning organization. Academy of Management Journal 40(5): 1150-1174.

Singh J, Goolsby JR, Rhoads GK. 1994. Behavioral and psychological consequences of boundary spanning burnout for customer service representatives. Journal of Marketing Research 31(November): 558-569.

Sinkula JM. 1994. Market information processing and organizational learning. Journal of Marketing 58(January): 35-45.

Sinkula JM, Baker WE, Noordewier T. 1997. A framework for market-based organizational learning: linking values, knowledge, and behavior. Journal of the Academy of Marketing Science 25(4): 305-318.
Slater SF, Narver JC. 1995. Market orientation and the learning organization. Journal of Marketing 59(July): 63-74.

Spanos YE, Lioukas S. 2001. An examination into the causal logic of rent generation: contrasting Porter's competitive strategy framework and the resource-based perspective. Strategic Management Journal 22(10): 907-934.

Spender J-C. 1996. Making knowledge the basis for the dynamic theory of the firm. Strategic Management Journal, Winter Special Issue 17(Winter): 45-62.

Staten M, Umbeck J, Dunkelberg W. 1988. Market share/market power revisited. Journal of Health Economics 7(March): 73-83.

Taylor JC. 1971. Technology and Planned Organizational Change. Braun-Brumfield: Ann Arbor, MI.

Walsh JP, Ungson GR. 1991. Organizational memory. Academy of Management Review 16(1): 57-91.

Zahra S, Covin J. 1993. Business strategy, technology policy, and firm performance. Strategic Management Journal 14(6): 451-478.

\section{APPENDIX: MEASUREMENT SCALE ITEMS a}

\section{IT Competency}

IT knowledge (Cronbach's $a=0.912)^{\mathrm{c}}$

Overall, our technical support staff is knowledgeable when it comes to computer-based systems.

Our firm possesses a high degree of computer-based technical expertise.

We are very knowledgeable about new computer-based innovations.

We have the knowledge to develop and maintain computer-based communication links with our customers.

IT operations (Cronbach's $a=0.891)^{\mathrm{c}}$

Our firm is skilled at collecting and analyzing market information about our customers via computer-based systems.

We routinely utilize computer-based systems to access market information from outside databases.

We have set procedures for collecting customer information from online sources.

We use computer-based systems to analyze customer and market information.

We utilize decision-support systems frequently when it comes to managing customer information.

We rely on computer-based systems to acquire, store, and process information about our customers.

IT objects (Cronbach's $a=0.811)^{\mathrm{c}}$

Our company has a formal MIS department.

Our firm employs a manager whose main duties include the management of our information technology.

Every year we budget a significant amount of funds for new information technology hardware and software.

Our firm creates customized software applications when the need arises.

Our firm's members are linked by a computer network.

\section{Organizational learning}

Information acquisition (Cronbach's $a=0.807)^{\mathrm{d}}$

We regularly meet with our customers in order to find out what their needs will be in the future.

We do a lot of in-house research that is directed at determining our customers' needs.

We view our customers as a source of market information.

We often ask our customers what they want or need.

We regularly collect information concerning our customers' objectives.

We often collect industry information from our customers by informal means (e.g., over lunch, at trade conventions). 
Information dissemination (Cronbach's $a=0.879)^{\mathrm{e}}$

Within our firm sharing customer information is the norm.

Within our firm, information about our customers is easily accessible to those who need it most.

Representatives from different departments within our firm meet regularly to discuss our customers' needs.

Within our firm, customer information is rarely shared between functional departments. ${ }^{\mathrm{b}}$

When one department obtains important information about our customers, it is circulated to other departments.

Information concerning our customers is readily available to each department within our firm.

Shared interpretation (Cronbach's $a=0.878)^{\mathrm{c}}$

There is often disagreement among our firm's managers with regard to what our customers want. ${ }^{b}$

In our firm, we often experience conflicting opinions with regards to how best to satisfy our customers. ${ }^{b}$

When faced with new information about our customers, our managers usually agree on how the information will impact our firm.

Managers in our firm tend to be on the same page when it comes to interpreting the needs of our customers.

Managers in our firm tend to agree on how best to serve our customers.

Declarative memory (Cronbach's $a=0.904)^{c}$

We retain information concerning our customers' overall business objectives.

We retain information concerning which markets our customers compete in.

We are knowledgeable about our customers' strengths and weaknesses.

The competitive positions of our customers are known to us.

We possess information concerning our customers' R\&D efforts.

We know a lot about our customers' sales goals.

We know what marketing strategies our customers have used in the past year.

Procedural memory (Cronbach's $a=0.782)^{c}$

We have a set procedure for handling routine purchase orders from our customers.

We have learned from past experience how best to deal with 'hard to please' customers.

We have standard procedures that we follow in order to determine the needs of our customers.

We have a standard procedure for effectively dealing with customer complaints.

Experience has taught us what questions to ask our customers.

3. Firm performance (Cronbach's $a=0.800) \mathrm{f}$

Customer retention

Sales growth

Profitability

Return on investment

4. Market power (Inter-item correlation $=0.816)$

Market share $\mathrm{g}$

Firm size ${ }^{\text {h }}$

a. Unless otherwise noted, all items were measured using a 7-point Likert scales with $1=$ Strongly disagree, $2=$ Disagree, $3=$ Somewhat disagree, $4=$ Neither agree nor disagree, $5=$ Somewhat agree, $6=$ Agree, and $7=$ Strongly agree .

b. Item reversed.

c. New items.

d. Adopted from Baker and Sinkula (1999).

e. Adopted from Baker and Sinkula (1999) and Kohli, Jaworski, and Kumar (1993).

f. Assessed how the firm had performed on each of the variables during the last 3 years, relative to competitors.

g. Measured on a 5-point scale with $1=$ Have a much larger market share, and $5=$ Have a much smaller market share, and using the following statement: "Relative to our firm's largest competitor, we ..."

h. Measured on a 5-point scale with $1=$ Are much larger, and $5=$ Are much smaller, and using the following statement: "Relative to our firm's largest competitor, we ..." 